\title{
Familial Breast Cancer - a Personal View on the Progress of the Past 30 Years
}

\author{
Michael Baum \\ The Portland Hospital, London, United Kingdom
}

I was delighted to be invited to submit an editorial for the first issue of BREAST CARE. As the theme of this issue is familial breast cancer I thought that it would be appropriate to write something on the history of breast cancer in my own family.

My mother died from metastatic breast cancer on my birthday, the 31st of May, 30 years ago, in the year I embarked on my academic career as Senior Lecturer in the department of surgery at the University Hospital of Wales. She also was at the age I now sit down to write. About 10 years ago my sister, the youngest of 5 siblings, was diagnosed with breast cancer and is alive and well to this day and is about to celebrate her 60th birthday. Although I am the last to rely on anecdotes in lieu of evidence, I believe the extreme contrast in the experience between my mother's and sister's cases effectively bracket my professional lifetime's experience of the disease. My mother Mary was the matriarch of a large orthodox Jewish family with extreme academic ambitions in the days before households were equipped with electrical appliances. Throughout the dark days of the Second World War and the blitz, she selflessly brought up a family of five children, together with a variable number of waifs and strays displaced or orphaned by the war. In those days the 'big C' was unmentionable and stigmatised; in fact to this day I am unaware of the cause of death of my maternal grandmother, although I have my suspicions. The first I knew of my mother's impending death was witnessing her climbing upstairs in the house, holding her back and dragging her foot. This image is clearly imprinted on my memory as it was one of those rare visits to the family household by a young surgeon preoccupied by his professional development and impossible workload, together with the call on his time of three children under the age of seven. My mother dismissed my concern by claiming it was just another bout of 'sciatica'. Ultimately the skeletal metastases from her breast cancer were diagnosed when her right breast was found to be replaced by a malignant mass. How long it had been there and whether or not she was aware of this, because of her inherent modesty, will remain a mystery. Although treatment was palliative in intent, the toxic side effects of the chemotherapy in vogue at that time haunt my memory. Worst of all from her point of view, was complete loss of her beautiful raven locks of hair. Her hair, always piled high in a complex chignon, was a constant source of pride and her baldness inadequately covered by a scarf, was a source of humiliation. Furthermore, and to my lasting shame, I never challenged my father's wish that my mother should be denied knowledge of her diagnosis. Clearly she was no fool and must have known what was going on, because out of the four medical sons she had mothered, it was always me, the 'breast cancer specialist', that she came to for explanations. Inevitably the last few months of her life for me were spoiled by the charade we played - I knew that she knew; she knew that I knew that she knew, and yet never was I allowed to discuss her illness in an open fashion. She suffered very badly from the pain of skeletal metastases with the side effects of chemotherapy adding insult to injury.

Twenty years later her youngest child, my sister, became aware of a $1.0 \mathrm{~cm}$ nodule in the upper central portion of her left breast. Prompt referral to a specialist and triple assessment by clinical examination, ultra-sound scan and biopsy confirmed a stage I breast cancer. She underwent wide local excision and level I/II axillary lymph node dissection. The tumour was grade II, lymph node negative and ER/PgR positive. Following surgery she underwent a course of radiotherapy to the breast followed by 5 years of tamoxifen.

These two anecdotes although of very personal significance, strikingly demonstrate the progress that has been made in the sociology, understanding, diagnosis and management of breast cancer. Also as I point out below these narratives provide necessary insights and directions for future progress.

\begin{tabular}{ll}
\hline KARGER & ๑ 2006 S. Karger GmbH, Freiburg \\
Fax +49 7614520714 & Accessible online at: \\
$\begin{array}{l}\text { E-mail Information@Karger.de } \\
\text { www.karger.com }\end{array}$ & www.karger.com/brc
\end{tabular}

Michael Baum, MB, ChM, MD(hon), FRCS, FRCR 
My mother's generation was probably the last to treat the diagnosis of breast cancer as a taboo. Furthermore, she was probably of a generation and culture whose modesty resulted in significant delays in the presentation with the disease. I am, of course, well known for my scepticism about the correlation between delay and outcome as far as survival is concerned, yet I have to believe that there is a significant minority of cases where prompt diagnosis will lead to prolongation of life that is above and beyond that of lead time bias. I also believe that diagnosis when the tumour is small and operable provides a much better chance for local control with breast preservation. Her symptom control during her terminal illness was inadequate but I can now take some pride in the British lead movement of palliative care. These days she would not have suffered so terribly. At the same time the chemotherapy contributed little to improvement in her quality of life and her alopecia was devastating. Sadly I have witnessed little improvement in this field of treatment over the last 30 years. As a pointer to the future I must re-emphasize that the diagnosis of metastatic breast cancer today is still a death sentence. The chemotherapy is still cruel and outside its specific use for symptom control it is still of marginal value for the prolongation of life.

Coming now to my sister, with the sociological changes and breast cancer awareness, there were no delays in her diagnosis. She was the beneficiary of a one-stop clinic where triple assessment was performed and a diagnosis established within a few hours. Her surgery was minimal but sufficient to achieve local clearance and pathological staging of the disease, allowing breast preservation and a good cosmetic result but she still had to suffer the rigours of 6 weeks treatment in a bunker under the baleful beam of a linear accelerator. Since my mother's death the nature and function of steroid hormone receptors had been worked out and the benefit of 5 years of tamoxifen had been established for the phenotype of my sister's tumour.

The final signpost for the future emerging from my family history concerns genetic predisposition. I suspect, although I can- not confirm, that there have been three generations of women affected with breast cancer, in a family of Ashkenazi descent. If that is the case then there is a significant probability of my family carrying a germ line mutation in the BRCA I/II domains. My sister has four daughters aged between 21 and 33 . On balance of probabilities therefore at least one of them should have inherited the mutant gene if in fact it does exist. The oldest of my nieces consulted me earlier this year and after independent counselling and with the support of her mother we embarked on the quest for the test. The story has a happy ending as we discovered that my sister carries none of the Ashkenazi mutations of the BRCA genes that predict the breast cancer risk. Of course that still leaves us with a familial risk related to life style or another gene with low penetrance. Even if that is the case I think we can look forward to further spectacular advances in the next decade. I look forward to the day when the success of treatment will leave so little room for improvement that we can at last abandon the ideology of screening [1]. One day soon I hope we can abandon 6 weeks of whole breast irradiation with one shot of intra-operative radiotherapy to the index quadrant [2]. One day all adjuvant treatments will have a biological rationale based on molecular pathology. Finally as a surgeon I look forward to the day that surgery itself may be abandoned for this disease because of primary medical therapies - and who knows this might even avoid the initial peak in the hazard of relapse induced by the operation itself [3]!

\section{References}

Baum M: The Breast Screening Controversy - Point of View. Eur J Cancer, 1996;32A:9-11.

2 Vaidya JS, Tobias JS, Baum M, Keshtgar M, Joseph D, Wenz F, Houghton J, Saunders C, Corica T, D'Souza D, Sainsbury R, Massarut S, Taylor I, Hilaris B: Intraoperative radiotherapy for breast cancer. Lancet Oncol 2004;5:165-173.

3 Baum M: Does the act of surgery provoke activation of 'latent' metastases in early breast cancer? Breast Cancer Res 2004;6:160-161. 